\title{
ПРО МЕТАМОВУ ГУМАНІТАРНОЇ НАУКОВОЇ ДУМКИ
}

\author{
Володимир Вахрушев
}

Доктор філологічних наук, професор, Балашов, Саратовська обл. (РФ)

\section{Ігор Козлик \\ (перекладач)}

Доктор філологічних наук, професор, завідувач кафедри,

Кафедра світової літератури і порівняльного літературознавства, Прикарпатський національний університет імені Василя Стефаника (УКРАЇНА),

76018, м. Івано-Франківськ, вул. Шевченка, 57,

e-mail: ihor.kozlyk@pnu.edu.ua

\section{PЕФЕРАТ}

У статті на основі поширення теорії гри на пізнання феномена художнього тексту та залучення досвіду розвитку філософської думки 2-ї половини ХХ ст. висвітлено проблему метамови гуманітарної науки.

Ключові слова: метамова, художній текст, гуманітарна наука.

\section{ABOUT THE METALANGUAGE OF HUMANITARIAN SCIENTIFIC THOUGHT}

\author{
Volodymyr Vakhrushev \\ Professor Doctor Habilitatus of Philology, \\ Balashov, Saratov region (RF) \\ Ihor Kozlyk \\ (translator) \\ Professor Doctor Habilitatus of Philology, Head of Department, \\ Department of World Literature and Comparative Literary Criticism, \\ Vasyl Stefanyk Precarpathian National University (UKRAINE), \\ 76018, Ivano-Frankivsk, 57, Shevchenko str., \\ e-mail: ihor.kozlyk@pnu.edu.ua
}

\begin{abstract}
The article is devoted to the problem of metalanguage of humanities basing on the spread of theory of game to the understanding of the artistic text phenomenon and the involvement of experience in the development of philosophical thought of the 2 nd half of the twentieth century.

Key words: metalanguage, artistic text, humanities.

Найперше я висловлюю глибоку вдячність керівникам Саратовського Міжрегіонального центру 3 вивчення художнього тексту Борису Львовичу Борухову та Костянтину Федоровичу Сєдову за люб'язне запрошення на цю конференцію. Про здійснену ними та їхніми колегами з країн СНД велику роботу мені вже довелося надрукувати відгук у журналі «Волга» [41]. Певна річ, ця рецензія через надто малий обсяг виявилася побіжною й
\end{abstract}


імпресіоністичною. Тепер хотілося 6 покладені в ii основу враження експлікувати і доповнити деякими судженнями узагальнюючого штибу.

Безумовно, центри на кшталт Саратовського потрібні хоча 6 тієї причини, що вони дають можливість нам, філологам та мистецтвознавцям, виговоритися, перетворити наші природні амбіції в слово, в текст. Як казав поет,

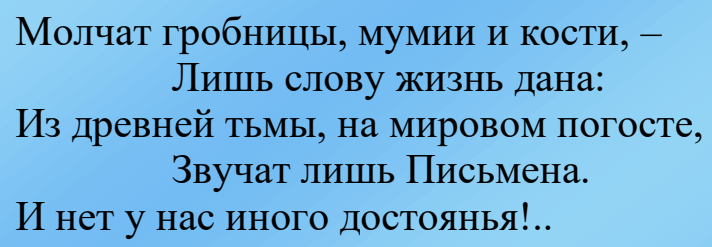

Так висловився у січні 1915 року І. Бунін. I ми всією душею співпереживаємо $з$ поетом - бо й від нас щось може перейти до нащадків? Рукописи, тексти, «письмена». Хоча, до речі, у чудових рядках майстра критик може помітити і неточність: чому гробниці та мумії «мовчать»? $\mathrm{Hi}$, вони теж промовляють і говорять багато історикові культури. І у кісток є своя «мова». $\mathrm{C}$ своя мова й у нас, філологів і мистецтвознавців. Взагалі, наше становище парадоксально-діалектичне: ми, так би мовити, «язичники», що купаються у «художньому тексті», живлять цим текстом свою науку, та цей статус творців науки змушує нас створювати свою мову, метамову (щодо «художнього тексту», далі скорочено - ХТ), яка, за своєю інтенцією будучи спрямованою на полегшення розуміння ХТ, фактично його затемнює, а часом навіть позбавляє сенсу! Гадаю, це лише окремий (але <від> цього не менш сумний) випадок загального стану справ у світовій культурі, вхопленого ще у Ніцше i Шпенглера, - парадигми науки настільки ускладнюються й уточнюються, що відриваються від земного свого коріння і в принципі відмирають, стають чужими живому життю, яке за усієї своєї таємничої надскладності зберігає, однак, $\mathrm{i}$ «нечувану простоту» ${ }^{1}$.

Втім, цей парадокс життя (який я пов'язую з категорією гри) пародійно, я би сказав (чи, інакше кажучи, іронічно), відображається і в нашій метамові текстових досліджень. Багато хто з гуманітаріїв, піддавшись духу сучасного сцієнтизму і ніби переспівуючи ранні етапи вітчизняного структуралізму, навіть пишаються тим, що їм вдалося ускладнити свою мову, свою систему аналізу ХТ. Ось характерний приклад. Н. В. Лозовська (СПб.) у повідомленні «Принцип моделювання у вивченні казки» зазначає: «Щоб зменшити небезпеку дослідницького свавілля, ми пропонуємо ще більше ускладнити і без того вельми громіздкий аналіз сюжетної належності казкового тексту, бо цього вимагає сама складність студійованого питання» [25]. Похвальна відвертість, але сама інтенція дослідника, як на мене, i не виправдана матеріалом i

\footnotetext{
1 «Нечувана простота» (рос. «неслыханная простота») - вислів з передостанньої (шостої) строфи 11 розділу поеми Б. Л. Пастернака «Волны» 3 його поетичної книги «Второе рождение» (1930-1931). Ця строфа звучить так: «В родстве со всем, что есть, уверясь / И знаясь с будущим в быту, / Нельзя не впасть к концу, как в ересь, / В неслыханную простоту» [31, с. 351]. «Нечувана простота», зазначає Б. М. Гаспаров, не тільки «щось більше, ніж простота стилю», вона, за апостолом Павлом, означає «здатність бачити світ „просто”, без допомоги тусклого скла і без роздробленості на частини; Пастернак позначає цей стан як „родство со всем, что есть”» [див.: 12]. (Прим. пер.).
} 
неприйнятна для філології. Вченому в даному випадку (а скільки їх, таких випадків!) бракує діалектики у підході до матеріалу. Хто сперечається, казка складна. Але ж вона і проста! Це, до речі, підтверджує і конкретний аналіз варіантів казки «По щучьему веленью», розгорнутим у тій же доповіді автором. Жодної обіцяної нам «надскладності» в аналізі немає - i це добре. Зате є добротний - в дусі $\mathrm{B}$. Проппа - розгляд «елементарної кумулятивної структури» епізодів казки ${ }^{2}$. Проголошене ж «ще більше ускладнення» метамови дослідження залишилося, на щастя, нереалізованим.

Ще подібний приклад, коли інтенції дослідника, його настанова на ускладнення проблем дає на практиці вихід цілком простий, який просто ігнорує цю складну «метамовну» теоретичну конструкцію. Б. І. Богін (Твер) пише: «Протиріччя між культурою письма і свободою читання (ця опозиція мені видається некоректною. - B. B.) розв'язується самою специфікою інтенціональності: безпосередній результат авторського акту - не „готовий сенс всередині душі", а лише накопичення ноем (мінімальних смислових одиниць, за обсягом зіставних 3 семами як одиницями аналізу значень). Внаслідок інтенціонального акту ноеми збираються „на краю” онтологічної конструкції» [2, с. 7-8]. Звичайно, це «зібрання ноем на краю конструкції» - гарна метафора. Але чому цим ноемам потрібно тулитися саме «на краю»? Невже автор ХТ такий недбалий до них? Між тим Г. І. Богін «нещадний» і до них, и до читача ХT: останньому доводиться «самостійно добудовувати чи повністю будувати свою власну конфігурацію усіх $(!-B$. В.) зв'язків і стосунків між всіма $(!-$ $B . B$.$) ноемами». Просто не читач, а шаховий гравець, який повністю$ перебудовує композицію фігур на дошці!

Далі як приклад дослідник називає роман «Американська трагедія» «великого» (! - B. В.) письменника Драйзера, відзначений нібито «стилістичною красою». Вона, ця «краса» (рос. «великолепие») продемонстрована двома цитатами 3 роману. Перша - думки Клайда, який пишається підвищенням по службі: «Как важно получать 25 долларов в неделю! Быть во главе цеха, где работает 25 девушек! Снова носить хороший костюм! Сидеть за начальническим столом...»³. Друга цитата - 3 роздумів героя про Роберту: «О, эта его связь с Робертой. Ведь кто она, в конце концов? Фабричная девушка... В то время как он - он - если б только судьба ему

\footnotetext{
2 Кумуляція (від лат. cumulatio збільшення, нагромадження, скупчення) - спосіб побудови сюжетної композиції фольклорних творів, який полягає у приєднанні однорідних мотивів у певному порядку до зазначеної межі. Як стилістичний прийом, полягає у багаторазовому повторенні певних елементів твору, характерних ознак, дій, вчинків та ін., для посилення його смислу, динаміки, емоційности. Кумулятивний принцип застосовується у замовляннях, казках, колискових піснях й ін. фольклорних жанрах. Приклад аналізу кумулятивної структури в фольклорній українській казці див.: [40]. (Прим. пер.).

3 Точна цитата цього місця з роману Т. Драйзера (початок XII розділу другої книги) у перекладі російською 3. А. Вершиніної та Н. Галь має такий вигляд: «Получать двадцать пять долларов в неделю! Заведовать отделением, где работают двадцать пять девушек! Снова прилично одеваться! Сидеть за служебной конторкой в углу у окна, откуда открывается прекрасный вид на реку! - и, наконец, после двух месяцев тяжёлой работы в жалком подвале чувствовать себя довольно значительной особой на этой огромной фабрике». Пор. у перекладі українською І. Буше, Л. Смілянського та Л. Ященко: «Одержувати двадцять п’ять доларів на тиждень! Завідувати відділом, де працюють двадцять п’ять дівчат! Знову пристойно одягатися! Сидіти за службовою конторкою в кутку біля вікна, звідки видно таку прекрасну ріку! - i, нарешті, після двох місяців важкої праці в паскудному підвалі почувати себе досить значною особою на цій величезній фабриці». (Прим. пер.).
} 
немного улыбнулась!» ${ }^{4}$ I ось у цих найпростіших «конструкціях» вчений закликає нас побачити «такі ноематичні комплекси, оволодіння якими приводить читача до інших конфігурацій $(!-B$. В.) зв'язків і стосунків в ноематичних ситуаціях», до «смислів, які в багатьох випадках і не входили зовсім в інтенціональну програму автора» ${ }^{5}$. Проте Драйзер, згідно 3 Б. І. Богіним, настільки великий, що він «вільно або невільно» створив у своєму ХT «програму читацького програмування інтенцій та інтендіювання ${ }^{6}$ » (! B. B.). Уся ця «програма програмування» (ось вона, наша метамова у всій своїй красі!) надто вже хитромудра, хоча, треба думати, сам письменник про таку і не підозрював. До того ж, якби Драйзеру довелося з цим текстом ознайомитися, він міг би висловити і легкий подив - як же так, якщо до його письменницької інтенції ноеми зібралися тільки «на краю» онтологічної конструкції його XТ, то яким чином він зміг таки створити цілі «ноематичні комплекси», та ще й «стилістично чудові». I ще одне - якщо письменнику довелося створити «програму програмування» інтендіювання, то яким чином «запрограмований» читач буде «повністю будувати свою власну конфігурацію усіх зв'язків» ХT, які, як виявляється, «не входили зовсім в інтенціональну програму автора»?

Залишається один висновок - легше забути про ХТ і всіх його творців, та й засісти нам самим за комп'ютери, щоб запрограмувати такі онтологічні конструкції, в які інтендіювались би такі ноематичні комплекси, які комуніціювали ${ }^{7}$ б споживачам ваших програм потребу в побудові власних програм, власних ноемних конфігурацій! Це, власне, і є базова інтенція нашої метамови дослідження XТ - редуціювання творця до статусу машини, що мислить.

Інтенція, на щастя, в принципі нездійсненна. Бо скільки б ми не

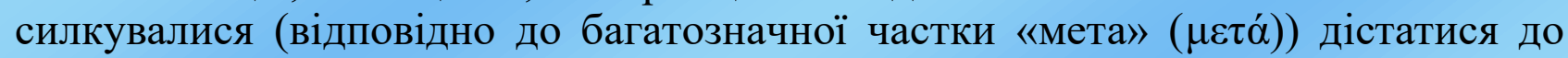
прихованих глибин ХТ, надбудовуючи над ним усе нові поверхи мовних універсалій), нам неможливо все ж вискочити повністю 3 «пут» природної мови. Добре сказав американський лінгвіст Бенджамін Лі Ворф: «Ми живемо в інтелектуальній в'язниці, стіни якої - структурні правила нашої мови» [цит. за: 27, p. 142]. А в'язниця інтелектуальна не може не бути діалектичною порушник іï правил одержує результати, протилежні очікуваним (приклади, наведені вище, це підтверджують). I навпаки, той, хто приймає їі правила (багато в чому таємничі), отримує майже (не повністю, а майже) необмежені можливості.

\footnotetext{
4 Точна цитата цього місця 3 роману Т. Драйзера (розділ XXII другої книги) у перекладі російською 3. А. Вершиніної та Н. Галь має такий вигляд: «В конце концов что такое Роберта? Фабричная работница! Ее родители живут и работают на ферме, и она должна сама зарабатывать свой хлеб. Тогда как он... он... Если б только судьба улыбнулась ему!» Пор. у перекладі українською І. Буше, Л. Смілянського та Л. Ященко: «Кінець кінцем, що таке Роберта? Фабрична робітниця! Ї̈ батьки живуть і працюють на фермі, і вона мусить сама заробляти свій хліб. Тоді як він... він... якби тільки доля посміхнулася йому!..» (Прим. пер.).

${ }^{5}$ На полях дописано: «Простіше було б сказати про іронію стосовно героя, його думок». (Прим. пер.).

${ }^{6}$ Інтендіювання (рос. интендирование) - створення спрямованості рефлексії для вказівки на «топоми духу», тобто відправні точки променя рефлексії, що йде назовні. Інтендіювання вказує на екзістенціальні смисли, майже однакові у представників усього людства. Тому техніка інтендіювання забезпечує можливість бачення інших національних чи індивідуальних менталітетів на основі фронатльної мобілізації всіх засобів рефлексивної реальності («душі») як відстійника досвіду. [Див.: 20]. (Прим. пер.).

${ }^{7}$ Комуніціювання - спілкування, пов'язаність, взаємодія. (Прим. пер.).
} 
На мій погляд, усі наші спроби осягнути неосяжне за допомогою «комп'ютерної» метамови неминуче ведуть до внутрішніх суперечностей в наших теоріях чи, у кращому разі, до такої їхньої неповноти, яка теж дискредитує подібні «повітряні» побудови. Ось ще приклад. В. М. Мейзерський (на жаль, вже покійний дослідник із Одеси) у повідомленні про прагматичні аспекти організації тексту [див.: 28$]^{8}$ дає серйозний i, наскільки я можу судити, цілком правильний аналіз «сигніфікації та дистрибуції текстових модальностей ${ }^{9} »$. Він пише про «фігуративацію ${ }^{10}$ висловлювань в театральних дискурсах», про «фокалізацію» ${ }^{11}$, яка допомагає забезпечити «складення первісної наративної структури» тощо. Але до яких конкретних висновків 3 аналізу ХТ приводять ці теоретичні розмірковування? Зокрема, учений пише: канонічні євангелія - це «добре організований корпус» текстів. Це оціночне означення «добре» виводить нас за межі метамови. У якому розумінні $\epsilon$ «добрим» цей корпус? Дослідник, мабуть, має на увазі якусь інтертекстуальну узгодженість усіх чотирьох євангелій щодо кореляції різних видів тексту як усередині кожного з них, так і між самим євангеліями. Але якщо це так, то навряд чи ці спостереження підтвердять «семантичний» аспект висновку, мовляв, «зміна ієрархії модальностей», скажімо, між текстами Матея і Луки, «дозволяє ставити питання про допустимі межі варіювання євангельської ідеології». Але ж це не так. Ідеологія Христа відзначена разючими суперечностями не тільки від одного євангелія до іншого, а й всередині одного типу дискурсу. Так, в Нагірній проповіді (Мт 5-7) Ісус починає з обіцянки «не порушувати» старозавітний закон чи заповіді пророків (Мт 5, 17-18), але відразу вдається або до уточнень, або до повного їхнього заперечення (Мт 5, 21-22, 43-44 й ін.). А в 10-му розділі Свангелія від Матея - ще один різкий поворот і ніби повернення Ісуса на старозавітні позиції. Звертаючись вже не до народу, а до апостолів, він прорікає: «Не мир прийшов я принести на землю, а меч» (Мт 10, 34). Але ж тип дискурсу той самий - пряме звернення суб'єкта мовлення до слухачів! Щоправда, у першому випадку Христос говорить перед «непосвяченими», а у другому - перед «обраними». Прагматичний статус дискурсу різко змінився через принципово інший характер адресата мовлення. Хоча, як бачимо, Христос здатний змінювати свою ідеологію і в межах одного типу висловлювання.

Цікаво, що творці нашої наукової метамови чудово бачать нездоланну

\footnotetext{
${ }^{8}$ Мейзерський Віктор Михайлович (1948-1990) - одеський вчений-гуманіст і філософ, кандидат філософських наук, доцент кафедри філософії Одеського державного ун-ту (тепер Одеський національний ун-т ім. І. І. Мечнікова). Студіював проблеми філософії мови та знакових систем. (Прим. пер.).

${ }^{9}$ Сигніфікація (від лат. significatio сигналізація, зовнішній прояв) - лінгвістичний процес фіксації значень (понять) за допомогою символічних засобів; позначення шляхом наділення яких-небудь реальних чи уявних об’єктів знаками (наприклад, словами). Дистрибуція (від лат. distributio поширення, розповсюдження) множина всіх оточень (контекстів), в яких зустрічається певний елемент, тобто безліч всіх (різних) можливих позицій цього елемента щодо позицій інших елементів. Модальність (від лат. modalis, лат. modus міра, спосіб) - це функціонально-семантична категорія, яка виражає відношення змісту висловлювання до дійсності і мовця до змісту висловлювання. Модальність може бути виражена інтонацією, морфологічними, лексикограматичними та іншими засобами. (Прим. пер.).

10 Фігуративація - те ж що і тропаїзація, тобто насиченість дискурсу мовно-стилістичними фігурами. (Прим. nep.).

11 Фокалізація ( $\not p$. focalisation фокусування) - термін Ж. Женетта, означає організацію оприявненої в оповіді точки зору і передбачає донесення ії до реципієнта (глядача чи читача). (Прим. пер.).
} 
перешкоду, яка знаходиться перед ними, та все ж не полишають зусиль подолати ї. Ось він, героїзм «штурмуючих небо», несамовитість «прометеїв духу»! Я маю на увазі зізнання авторів у тому, що «спроби раціоналістичного аналізу ХТ» приречені на невдачу [див.: 17, с. 20], що у «творчому мисленні» $€$ «ірраціональні конструкції» [1], що загалом в «художній творчості є якась таємниця, якесь надособисте начало» [35, с. 10] тощо. Цілком правильно мовиться про те, що «ейфорія 3 приводу успіхів лінгвістики тексту стає все менш виправданою» [8, с. 24].

3 огляду на це тішить стаття Б. Л. Борухова «Проблема точності і міф про математику», яка завершує збірник «АРТ» [див.: 3]. Вона присвячена не Ю. М. Лотману, а «сімдесятиліттю Ю. М. Лотмана», тобто творчій еволюції видатного філолога й історика культури, який фактично змушений був визнати неспроможність власних спроб математизувати методологію гуманітарних наук. Принагідно зазначимо - його колеги по тартусько-московській семіотичній школі тепер визнають і недоліки власної «метамови». Так, Б. М. Гаспаров пише про їхні зустрічі в Тарту: «Герметизм наукової спільноти підтримувався також прийнятою в іiі колі езотеричною мовою», це була особлива «семіотична» мова $[13$, с. 284-286]. А М. Л. Гаспаров відверто зізнається: ця мова «важко давалася» [14, с. 301]. Інші учасники школи, щоправда, вже схильні заперечувати особливу «закритість» їхньої мови [45, c. 304-305], зазначаючи, що «створення метамов опису семіотичних систем» мало лише «локальний характер» [24, с. 311].

У будь-якому разі можна стверджувати, що всі ці «метамови» головному їхньму творцеві у 70-ті та 80-ті роки в основному були вже не потрібні ${ }^{12}$.

Та повернемося до статті Б. Л. Борухова. Він чудово викладає історію загибелі міфу про «всемогутність» i чудодійну «строгість» математики, підкреслюючи іiі діалектичну природу. Автор легко спростовує і претензії деяких мистецтвознавців на особливу «точність» їхніх метаматизованих методів. I в кінцевому рахунку дослідник повертається до більш ніж традиційного висновку - наше дослідження ХТ «залежить вже від конкретного дослідника - від його таланту, інтуїції, сумлінності» [3, с. 191-192].

Але якщо так, то навіщо ж тоді вся наша прив'язаність до нових і новітніх підходів - до герменевтики, «текстики», дискурсивної семіотики, постструктуралізму, неориторики тексту, деконструктивізму? Ці напрями притягують нас все-таки настановою на точність, а дослідження всіх видів культури, на думку Б. Л. Борухова, «не тільки може, а й повинно бути точним». Та ось тут, у проблемі розуміння «точності», я хотів би посперечатися 3 шановним колегою. Тут його метамова, як на мене, дає збій, бо не враховує деякі чинники онтології культури. Б. Л. Борухов правильно розрізняє два різних значення терміну «точність» - «істинність» та «строгість, відповідність формальним процедурам» дослідження. Та чи можна на цьому зупиняти аналіз XT? У жодному разі. По-перше, саме поняття «точність» метафоричне і значно багатозначніше, ніж це подано у тлумаченні мого колеги, по-друге, сам ХT ще більше багатозначний, так що по суті, прагнучи до «точного» аналізу тексту, ми

12 На полях дописано: «Точніше, вони були ним по-гегелівськи „усунуті” (aufgehobt)». (Прим. пер.). 
намагаємося визначити неосяжне невизначеним - а це апорія, яка не поступається за складністю зенонівським ${ }^{13}$.

Почнемо 3 «точності». Вона має той самий корінь, що й слово «точка», а остання є конгломератом значень - фізичного («точка» - від дієслова «ткнути» або «ткати»), геометричного (зникаюче малий ідеальний параметр вимірювання) і філософського. Про останнє розмірковував неоплатонік Прокл, а його міркування у тлумаченні О. Ф. Лосєва ставали цілою поемою в прозі. В точці, виявляється, сходяться протиріччя Буття, хоча вона i «надбуттєва. Космічний круго́біг - ось образ точки. За Проклом, точка є перехід ейдосу в матерію. Будь-яка точка вирує своїми смисловими енергіями, які не можуть не литися в фоні, що піi оточує. I точка не просто розливається, вона приховує в собі і ті цілісні структури, які з неї виливаються і якими вона керує. Вона не $\epsilon$ просто єдність, а є принципом будь-якої єдинороздільної цілісності... Вона є і виражальною потугою будь-якого цільного буття і саме́ це цільне буття... Точка - прекрасна» [26, с. 151-152].

Усі ці виклади й етимологічні екскурси не скасовують, звичайно, сучасних «технічних» конотацій терміна «точність», але мистецтво - гадаю, 3 цим усі погодяться - куди доречніше «вимірювати» саме тією «точністю», яку мав на увазі античний філософ. Адже точка, з позиції неоплатонізму, та й філософських поглядів О.Ф. Лосєва, виявляється не так одиницею вимірювання (хоча і нею теж), як «атомом» і життя, і естетичних явищ.

Тепер подивимось, наскільки «точність» може узгоджуватися з істиною в оцінці ХТ. Філософську основу категорії істини грунтовно дослідив у своїх роботах М. Гайдеггер. У його праці «Про сутність істини» (1961) [див.: 19, с. 827] ця сутність постулюється як «свобода», котра, своєю чергою,

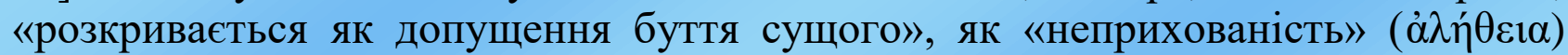
буття в його «простоті простого», схопленого первісно ще поза-раціонально, «безпоняттєвим виявленням». Але діалектика існування людини в історії $\epsilon$ такою, що суще для неї «закривається і спотворюється» (через, доповнимо ми, відчуження людини від природи, від своєї власної сутності). Однак це спотворення істини є необхідним моментом i існування. «Істина і неістина в сутності не байдужі одна одній». Філософ стверджує навіть більше: на його думку, «прихованість сущого в цілому, тобто справжня не-істина, давніша, ніж будь-яка відвертість того чи іншого сущого». «Загалом таємниця (прихованість прихованого) як така панує над наявним буттям людини». I це основа екзистенції людини. Тільки «блукаючи» $\mathrm{i}$ «помиляючись», історичне людство може виходити на шлях істини.

Цей діалектичний шлях розкриття істини 3 «неістини» (= майї ${ }^{14}$, ілюзіï) Буття просто-таки дублюється (трансформуючись по-своєму) усією історією світового мистецтва, самим його онтологічним статусом. Якщо буття - це «гра»

\footnotetext{
13 Апорії Зенона (від др.-грец. $\alpha$ торі́ $\alpha$ безвихідність) - зовнішньо парадоксальні міркування на тему про рух і множину давньогрецького філософа V ст. до н.е. Зенона Елейського. (Прим. пер.).

${ }^{14}$ Ма́йя (санскр. माया, та̄уа̄, букв. ілюзія, видимість) - в індійській релігійно-філософській традиції особлива сила (шакті), або енергія, яка одночасно приховує істинну природу світу і забезпечує різноманітність його оприявнень. (Прим. пер.).
} 
(див. відоме висловлювання Геракліта: «Вік - дитя, що грається, кості кидає, дитя на престолі!»), то тим паче «грою» стає і мистецтво, про що говорили I. Кант та Ф. Шіллер. Воно, як зазначив ще Арістотель, каже не про те, що насправді відбулося, «а про те, що могло би статися, а значить, про можливе за ймовірністю або за необхідністю» [6, с. 449-450]. Інакше кажучи, це світ алетичних модальностей ${ }^{15}$, в яких панує «знаковість в степені $\mathrm{N}$ як відмінна властивість ХТ» (заголовок доповіді К. А. Долиніна [7, с. 22]), де «семантика ХТ» породжує «можливі світи» [див.: 21].

Якою має бути природа «точності» для виміру цих художніх «світів»? Тільки метафоричною, тобто такою, яка осягає ХТ одночасно на багатьох рівнях - на раціональному й інтуїтивному, логічному й образному. Тут найдоречнішим є судження Ф. Ніцше: істина - це «пані метафор» або «армія метафор, метонімій та антропоморфізмів, що бадьоро крокує маршем», «істина - це ілюзії, про які забули, що вони ілюзії» [цит. за: 30, р. 58] тощо. 3 німецьким філософом не можна не погодитися, хоча серйозним теоретикам ця заява видається скандальною. А ось письменники ще задовго до Ніцше знали і відчували це. I відкрито допускали множинність істин у своїй творчості. Ф. Шіллер, наприклад, по-різному зображає полководця А. Валленштайна в «Історії Тридцятирічної війни» і в своїй трилогії про нього. I у поета готове виправдання, адже, на його думку, «трагедія $є$ поетичне зображення дії, достойної жалю, і тому вона протистоїть історичному зображенню» $[36$, с. 82$]$. Слідом за великим німецьким поетом, який естетично «грає» істинами, рухаються М. М. Карамзін (у якого Марфа Борецька в однойменній повісті представлена республіканкою-патріоткою, а в «Історії держави Російської» «інтриганкою»), О. С. Пушкін (порівняймо «двох» його Пугачових), В. Скотт, Байрон та інші. Відзначимо дивовижну одностайність усіх названих авторів у цій «грі»: вони в історико-документальних жанрах (дослідження, передмова, примітки) дають «знижену» версію істини про своїх персонажів, а в художній прозі та поезії - «піднесену» ${ }^{16}$. Звідси і знаменитий афоризм поета 3 його поезії «Герой» (1830). В ролі епіграфа Пушкін бере «вічне» філософське і євангельське питання «Що є істина?» Твір будується як діалог Поета і його Друга, які з'ясовують сутність істини «індуктивно», відштовхуючись від образу Наполеона. У переліку вчинків і справ імператора, в переборі властивостей його особистості письменник намічає два підходи. Один - «історичний» - явно не на користь Наполеона. Недарма «Друг» каже: «історик строгий гонить» геть «мрії поета», тобто відкидає романтичну ідеалізацію цього історичного діяча. Та останнє слово все ж залишається за «Поетом», в образі якого виступає сам Пушкін:

Тьмы низких истин мне дороже

Нас возвышающий обман...

\footnotetext{
15 Алетична модальність (від грец. aletheia правда) - категорія модальної логіки, що позначає необхідні та можливі судження дійсності, які виражають факт об'єктивної дійсності, не вказуючи на його логічну необхідність. Алетична модальність детермінується 3 погляду об’єктивних законів природи, суспільства й логічних законів. Це об’єктивна модальність. (Прим. пер.).

16 Як пародійно-знижений варіант цієї дихотомії див. вірш Пушкіна, звернений до А. П. Керн, і його епістолярні відгуки про неї.
} 
Ось вона, висловлюючись мовою Гайдегтера, «справжня не-істина» як необхідний діалектичний момент справжньої істини! Поет знає всю (наскільки вона тоді була відома) правду про Наполеона, та він знає і те, що вся вона може бути переважена одним «обманом» - якщо це «обман» художній, що створює нову реальність, яка дійсно збагачує нашу духовну ноосферу.

Так полягає справа 3 питанням «точності» мистецтва.

Але, власне, так саме потрібно вирішувати питання і з нашою наукою, з іiі метамовою. Адже вона, ця метамова, наскрізь метафорична. I - в цьому сенсі іронічна (що я і намагався показати на деяких прикладах). Проте тут іронія ненавмисна, об'єктивна, звернена проти творця цієї мови - попри його волю. Тож чи не краще відкрито визнати цей факт і обернути цю іронію на свою користь? Власне, так і чинили багато видатних умів - від глибокої давнини до наших днів - згадаймо Платона, Геракліта, Прокла, Ф. Бекона, Берклі, Юма, К'єркегора, Вол. Соловйова, Шестова, П. Флоренського й ін. У другій половині XX століття Л. Вітгенштайн і Жак Дерріда підвели під цей напрям у науці і філософії металінгвістичну базу. Але перш ніж говорити про останню, зазначимо, що наука загалом, як одна $з$ форм культури, поряд з мистецтвом, за цілою низкою параметрів $\epsilon$ грою. Та інакше й бути не може - адже «грайливе» Буття (разом 3 Небуттям) може породжувати лише «грайливі» форми свого власного відображення, чи, інакше кажучи, можливі світи, що перебувають у стані гри. Н. І. Степанов, автор статті «Наука і гра: зіставлення й аналогія» [39] спочатку цитує працю Роже Кайюа «Що таке гра?» [4], а потім, спираючись на ці постулати, на спостереження таких учених, як М. Ейген, Р. Вінклер [див.: 9], В. Налімов, Д. Бом, В. Гейзенберг, А. Ейнштей та ін., обгрунтовує ігрову природу фундаментальної науки і наукової творчості. Не вдаючись до багатьох деталей і до окремих спірних проблем цієї солідно обгрунтованої теорії (до речі, саме слово «теорія» етимологічно i семантично близьке до давньогрецького терміна «театр»), спробуємо лише сформулювати одне 3 можливих визначень категорії «гра». Ми розуміємо при цьому, що гра - це поняття універсальне, яке характеризує один 3 важливих (a, може, й найважливіший) атрибутів Буття. Тому воно невичерпне і може бути визначене по-різному. Та, на мою думку, спільним у всіх цих визначеннях є таке: гра - це вічний процес взаємоперетворень Буття і Небуття, Сдиного і Множини, Сущого i Не-Сущого, Свободи і Необхідності, а також процес взаємоперетворень самого цього процесу в результат і результату в процес. Я бачу недоліки свого визначення, позаяк воно потребує тлумачення всіх термінів, які входять до нього, - та на даному рівні міркувань цього, гадаю, достатньо.

Природно, що і мова «подібна до гри», а отже, і будь-якій інтерпретації тексту, як зазначає Гадамер, неминуче судилося самовикористання. Вона повинна грати, тобто входити в гру, «усуваючи себе у своєму здійсненні» [11, c. 24]. Багато написано про «мовні ігри» Л. Вітгенштайна [див., хоча б: 42; 18; 38]. Проте особливо цікавим для нас $є$ деконструктивізм (хоча якраз з цим вченням я ще недостатньо ознайомлений). Його творець Жак Дерріда спирався у своїх поглядах як на досвід своїх предків - рабинів, екзегетів каббали, так і на судження Ф. Ніцше про метафоричну енергію мови, що тихцем підриває основи всієї європейської раціоналістичної культури. 3 таким же успіхом Дерріда - 
творець примарної «граматології» - міг би послатися і на досвід французьких символістів - Рембо i Малларме, італійських i російських футуристів, «мудрагелів» тощо. У будь-якому разі, як зазначає К. Норріс, «у творах Дерріди відчутна утопічна жага „вільної гри тексту”, яка могла б колись повністю порвати зі встановленими правилами мови» [30, р. 49].

Дерріда, певна річ, зовсім не пориває 3 цими «правилами», інакше його ідеї не могли б доходити до нас. Але його заслуга в тому, що він розширив i помітно змінив метамову дослідження ХТ тим, що наблизив цю метамову до мови самого XТ.

До речі, як я сам розумію ХТ? Сучасна філологія довела - i, гадаю, з цим ніхто вже не буде сперечатися, - що в основі своїй ХТ не відрізняється від «звичайного» тексту - розмовно-побутового, ділового, наукового, ораторського й ін. Вже історія романного жанру, як показав М. Бахтін, продемонструвала можливість включення будь-якого виду тексту в ХТ. Не торкаючись численних суперечок між текстологами і лінгвістами щодо об'єкта їніх наук, висунемо власне (найпростіше, як нам здається) визначення тексту. Текст - це будь-яка, обмежена чи необмежена сукупність знаків (будь-якого походження) i проміжків між цими знаками, об'єднана тими чи іншими видами зв'язків. У чому ж специфіка ХТ як одного з різновидів тексту загалом? У тому, як на мене, що це текст, у якому оприявнені образні його потенції. Скажімо, чийсь лист, виступ на мітингу чи інший документ, який аж ніяк не претендує на художність, потрапляє в роман, повість, п'єсу і стає деталлю, штрихом того чи іншого художнього образу - у цьому документі, в цьому не-художньому тексті, ми починаємо помічати художні якості - особливий ритм, стиль, манеру висловлювання, що розкривають душу героя, особливості його мислення, поведінки тощо. В принципі ж будь-який текст $є$ певним чином художнім ${ }^{17}-\mathrm{i}$ це підтверджує особливо практика XX століття, як би ми іï не оцінювали естетично.

Проте це старе (хоча не дуже вже й старе!) поняття «художній образ» явно в зневазі у багатьох сучасних дослідників ХT, захоплених структурнолінгвістичною термінологією. Ще б пак, адже як казав Новаліс, «саме слово „образ” образне». Значить, «неточне»! Щоправда, в останні роки з’явилася імагологія, спеціальна наука про структуру, розпізнавання і побудову образів. Та вона більше стосується природничих наук ${ }^{18}$. Виходить парадокс - поки філологи-структуралісти нехтують категорією образу в мистецтві, поринувши в математизовані теорії 3 їніми «релевантностями», «фігуризаціями», «конфігураціями», «лексемами» і «класемами» ${ }^{19}$, природознавці все частіше

\footnotetext{
17 В російськомовному оригіналі: «художествен». (Прим. пер.).

18 Це не зовсім точне судження, адже імагологія (від лат. imago зображення, образ) - це наукова міждисциплінарна галузь, яка вивчає закони створення, функціонування й інтерпретації не образів загалом, а саме образу «іншого», «чужого», стороннього для того, хто сприймає, об'єкта. В сфері літературознавства імагологічна проблематика входить у фахову площину сучасної літературознавчої компаративістики. (Прим. пер.).

19 Релевантність - здатність відповідати чому-небудь, бути істотним, важливим, доречним. У мовознавстві ступінь зміни значення однієї морфеми (насамперед кореня) під впливом значення іншої морфеми (передовсім афікса). В інформатиці і комп'ютерних технологіях - смислова відповідність між інформаційним запитом i одержаним повідомлення, здатність інформації відповідати потребам користувача. Конфігурація - обрис зовнішньої форми чого-небудь, взаємне розташування, розміщення якихось предметів або їхніх частин. В галузі
} 
стали звертатися до «образного мислення». Вони пишуть про те, як «виникають образи на грунті» - особливі «складні, ритмічно організовані структури» [32]. 3'явився новий напрям у комп'ютерному програмуванні - іміджинг (буквально «образотворчість»). Це «нова система образного кодування інформації», яка «дозволяє одержати відразу цільну картину» природного об’єкта дослідження, аналогічну твору малярства [див.: 33].

Звичайно, плідне використання категорії образу в природничих науках та інформатиці зовсім не свідчить, що вчені зобов'язані лише вітати іі. $€$ достатньо свідчень зворотного порядку. Так, психолог-біхевіорист Б. Скіннер проголошував: категорія образу - «головна небезпека для психології» [див.: 44, c. 205]. Деякі мистецтвознавці (Г. Вьольфлін, Б. Крістансен, та й Л. С. Виготський) заперечували образ навіть у мистецтві. Один 3 них пише: «метою зображення предметного в мистецтві є не чуттєвий образ об'єкта, а безо́бразне враження предмета... Головне в музиці - це нечутне, в пластичному мистецтві - невидиме і невідчутне» [5, с. 97, 109]. Та навіть якщо погодитися 3 цією думкою естетика, то вона - вже за законом тієї самої мовної ігрової іронії, про яку йшлося вище, - заперечує саму себе. Адже що таке «зображення предметного»? Слово «зображення» за своїм коренем належить до групи, об'єднаної поняттям «образ» (образ-ображ), і означає «створення образів». Значить, творити мистецтво, не створюючи образів, неможливо. Звісно, можна, нехтуючи чуттєвим виглядом образу (словами, звуками, фарбами, рухами), прагнути до осягнення глибинної його сутності, яка i виявиться якимось безтілесним концептом, «нематеріальним знаком матеріальних стосунків». Як казав філософ і поет Вол. Соловйов:

Милый друг, иль ты не видишь,

Что всё, видимое нами, -

Только отблеск, только тени

От незримого очами?

Нехай так. Але якщо «теорія» сягає «театру», то «ідея» - знову ж таки «образу» (обидва цих останніх поняття злились у давньогрецькому слові

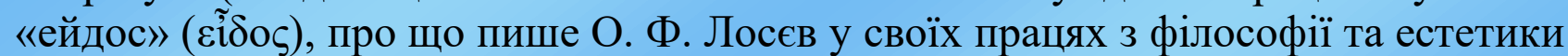
Платона ${ }^{20}$.

Не будемо займатися аналізом поняття «образ», бо це заведе нас далеко

інформаційних і комп'ютерних систем - певний набір комплектуючих, виходячи з їхнього призначення, номера та основних характеристик, а також сукупність налаштувань програми, задана користувачем та процес зміни цих налаштувань відповідно до потреб користувача. Класема - загальнокатегоріальна сема лексикограматичного значення, що вказує на належність слова до певної частини мови. Інакше кажучи, класеми - це найзагальніші змістові ознаки, які відповідають значенням частин мови: предметність, ознака, кількість, дія. (Прим. пер.).

20 Це дещо спрощений підхід В. С. Вахрушева до питання про тлумачення образу у мистецтвознавців, адже, скажімо, у Б. Крістіансена йдеться не про заперечення образу в живописі, а про неправомірність ототожнення образу з наочністю зображення. [Див. про це: 23, с. 182-183]. Крім того, треба зважати на те, що змістове наповнення теоретичних категорій варто виводити не з етимологічного (загальномовного) значення чи якихось асоціативних зв'язків лексем, а $з$ тієї конкретної теорії, яку вони втілюють. Нарешті апеляція до законів ігрової іронії у даному випадку свідчить, як на мене, про те, що В. С. Вахрушев перебільшував («слишком расширил», як зазначає Б. Ф. Сгоров у листі до мене від 17 серпня 2020 р.) роль гри в тлумаченні такого складного явища, як художньо-мистецька діяльність. (Прим. пер.). 
від теми доповіді. Зазначимо лише, що будь-який образ, наприклад, психологічний, що виникає у нашій свідомості чи «колективному несвідомому» просторі, або художній, що створюється творцем, мають в принципі одне «ігрове» підгрунтя. Образ - це діалектична єдність і взаємоперетворення елементів об'єктивної реальності і суб'єктивних уявлень, пов'язаних 3 цими «елементами», причому цей процес взаємодії в принципі нескінченний. Я сприймаю реальність - зовнішню та існуючу всередині мене, несвідомо для себе перекодовую усе сприйняте в образи, на основі цих образів створюю інші образи (образ мого «Я»), проекції образів, що виникають у моїй свідомості і підсвідомості, на дійсність, що змінюється під впливом цих образів, а це знову ж таки впливає на мене i т. д. Образ художній при цьому живе особливо інтенсивним життям, бо від гранично заряджений духовною енергією свого творця. Такий образ не просто «повертається» в реальність, але створює особливу «над-реальність», духовно-об'єктивний світ, у якому буття і небуття змагаються одне 3 одним і перетікають одне в одного. Як відзначив П. Флоренський, «художній тип згущує сприймання і тому правдивіше за саму життєву правду (хоча саме поняття правди, істини, як зазначено вище, вельми складне. - B. В.) і реальніше від самої дійсності. Раз відкритий, художній тип входить у нашу свідомість як нова категорія світосприйняття і світорозуміння» [10, с. 169].

Усі ці міркування про художній образ можуть видатися тривіальними. Але, як на мене, їх доречно нагадати, позаяк наша сьогоднішня метамова, «інтендійована» насамперед на дослідження формально-структурних закономірностей XT, категорію образу майже цілком ігнорує і цим мимоволі створює збіднене уявлення про мистецтво. Ось ще один приклад. К. Е. Штайн (Ставропіль) у дослідженні про гармонію поетичних текстів [див.: 37] висловлює немало цінних думок про організацію мовних і екстралінгвістичних елементів в ХT, про динаміку їхньої кореляції, про типи поетичного тексту. Але як виглядає у доповіді аналіз поезії Пушкіна «Я помню чудное мгновенье...»? «Звуковий комплекс (ти) стягує в один вузол семантичні, синтаксичні і звукові можливості тексту... Якщо у зовнішній течії тексту ти (займенник-актант ${ }^{21}$ ) має функцію відходу, то (ти) - семантизований звуковий комплекс характеризується функціями „незмінної присутності” ... відбувається взаємне відображення (f-ізотопний: $x$ (ти) - в $y($ ти)), внаслідок чого можна зафіксувати амбівалентність семантичних функцій, приписуваних суб'єктові (ти), що перебуває, своєю чергою, у стосунках причинної обумовленості з суб'єктом (я)» і т. і. Далі дослідник аналізує два тексти О. Кручених:

$\begin{array}{ll}\text { 1. О Е А } & \text { 2. Дыр бул щыл } \\ \text { И Е Е И } & \text { уб ешщур } \\ \text { А Е Е Ь } & \text { скум } \\ & \text { вы со бу }\end{array}$

21 Акта́нт (від лат. agere діяти) - семантичний (мисленнєвий) аналог особи або предмета у висловлюванні, мовленнєва конструкція, що доповнює значення предиката. Як правило, актант реалізовується в мові через підмет і додаток, рідко - через обставину. Актант є одним із підпорядкованих дії елементів, що увиразнюють ії значення, вважаючи актантом будь-яку істоту або предмет, що активно виконують дію чи навіть пасивно беруть у ній участь. 
Точніше, подані з Кручених три тексти, але я згадаю лише ці два. Перший виявляється «фонетичною полемічною цитатою», побудованою на «відшаруванні асонансної структури молитви „Отче наш” („О-тч-Е н-А-ш, И-жЕ Е-с-И”...)». У другому тексті «елементи можна інтерпретуати як 1) кореневі відшарування (дыр бул), 2) відшарування фіналей 22 слів (щыл) $(?-$ B. B.), 3) відхилення фіналей слів ініціальних частин „розрубаних слів” (убе, бу)» тощо. «Текст постає єдиним цілим» $(!-B$. B.), і хоча він «існує поза синтаксичних зв'язків», все ж він естетично цінний: адже «відшаровані елементи гармонізуються на основі симетрії їхнього розташування, а також звукового повтору».

Яким же $є$ результат дослідження? За допомогою усієї цієї лінгвостилістичної термінології автор вправно стирає різницю між Пушкіним і Кручених, між шедевром світової лірики, зведеним до «пермутації 23 актантів», i «жвавими» вправами футуриста, придатними лише для фонетичних забав.

$\mathrm{Hi}$, я рішуче відмовляюся від такої метамови дослідження, хоча у ній, звичайно, є свої сильні сторони. Я вважаю своїм обов'язком постійно вчитися у колег, підтримую їхнє прагнення до точності і глибини дослідження ХТ, але волію йти іншим шляхом - нехай цей шлях здається багатьом філологам застарілим і вже примітивним.

Йдеться про так званий цілісний аналіз, хоча саме́ сполучення «цілісний» i «аналіз», тобто розкладення цілого на частини, суперечливе ${ }^{24}$. Та це, на мій погляд, продуктивна суперечність, яка вписується в ігровий контекст культури. Наведу власний приклад такого аналізу. Мова йтиме про байку «Ворона i лисиця» в різних варіантах, що виникли у світовій літературі упродовж останніх двох тисяч років. На жаль, не залишилося записів семінару, який академік Л. В. Щерба вів протягом цілого року (приблизно 1925 р.) на словесному відділенні Інституту історії мистецтв. Семінар був присвячений зіставленню байки Лафонтена «Ворон і Лис» і криловської ii переробки. Слухачка Є. М. Іссерліна згадує, що Щерба проводив ці заняття блискуче, тлумачачи студентам кожне слово, кожну фразу двох авторів. Його заняття мали також і лінгвокраєзнавче спрямування [див.: 29, с. 135-136]. Враховую також і блискучий аналіз байки Крилова, здійснений Виготським [див.: 43, c. $154-157]$.

Ми будемо шукати інваріант декількох текстів, в яких розробляється тема «ворони і лисиці» і спробуємо довести, що це багаторазове звернення до теми породжує гру художніх образів, у якій стійка структура $з$ іï архетипами увесь час варіюється і врешті-решт навіть починає сама себе «деконструювати», бо суперечливість була в цій структурі закладена від самого початку (наскільки ми

\footnotetext{
22 Фіналь - кінцева буква (кінцевий звук) або сполучення кінцевих букв (звуків) у слові, які можуть зникати при словотворенні. (Прим. пер.).

23 Пермутація (від лат. permutatio зміна, заміна) - перестановка елементів, кожний із різних можливих варіантів розташування елементів. (Прим. пер.).

24 Теоретико-методологічне підгрунтя і деякі практичні аспекти цілісного аналізу літературно-художнього твору системно досліджував в українському літературознавстві один із фундаторів донецької філологічної школи, доктор філологічних наук, професор М. М. Гіршман (1937-2015). [Див.: 15;16]. (Прим. пер.).
} 
цей «початок» знаємо).

Для нас сюжет починається 3 прозової давньогрецької байки, яку традиційно приписують Езопу, хоча, напевне, до неї різні види «прототексту» усно побутували сотні років. А то і більше. Адже жанр байки у греків у «чистому» вигляді не виокремлювався - вона йшла під загальним родовим позначенням «міф» - «мютос» ( $\mu$ $\theta$ о $)$, а це слово вміщувало в себе неосяжний спектр значень - байку, казку, приказку, передання, оповідь (загалом), слово, мовлення, пораду, відомість, слух, задум, сюжет, предмет обговорення тощо. Виходячи 3 бездонних глибин міфу, байка за тисячі років встигла спеціалізуватися - вона і звузилася до суто «прикладного» й «нижчого» в мистецтві морально-дидактичного жанру і водночас спромоглася у кращих своїх зразках зберегти жанровий протеїзм - недарма О. Потебня та Л. Виготський вбачають у байці можливість «виходів» в епос, лірику, драму, роман.

Власне, в давньогрецькій літературі відомі два варіанти «езопівської» версії 25 . У першому йдеться про Во́рона, який вкрав шматок м’яса (бо́ $\chi \alpha \varsigma)$ (Лев Толстой, який недолюблював байки Крилова за їхню, нібито, «псевдонародність», докоряв байкареві і за введення чужого російському селянинові «сиру» в текст. Л. Щерба Крилова «виправдовував»). Лис ( $\alpha \lambda \omega ́ \pi \eta \xi)$ звертається до Ворона 3 такою промовою: «О Вороне, ти маєш гарну зовнішність (форму). Якщо маєш і голос, то ти не лише кращий серед кращих, а й цар орлів, яструбів і шулік» (' $\Omega \chi 0 ́ \rho \alpha \xi$,

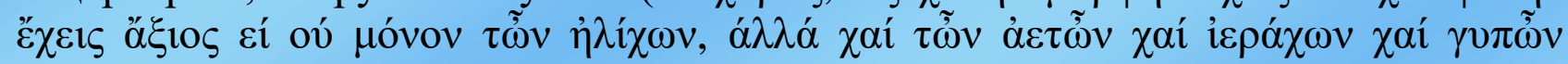
$\beta \alpha \sigma i \lambda \varepsilon v \varepsilon \varepsilon v)$. Ворон піддається лестощам і втрачає м'ясо. Лис, тікаючи за здобиччю, каже птахові: «Вороне, голос в тебе $\epsilon$, а розуму - нема» (' $\Omega \chi о \rho \alpha \xi$,

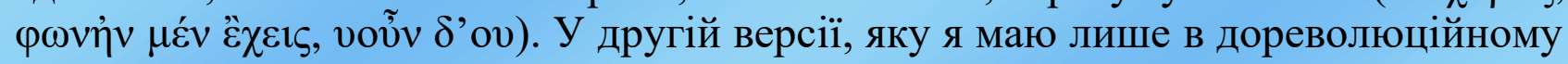
перекладі, замість «м'яса» фігурує «шматок сиру», промова Лисиці звучить дещо інакше: в ній вже намічається улесливий «портрет» Ворони. Йдеться про iї «пір'я найцарственнішого кольору». Додана мораль: «Не вір ворогам - добра не вийде» ${ }^{26}$. У цих початкових для нас версіях, що склалися, можливо, років за п'ятсот до нашої ери, вже сформована вся структура байки. Вона буде тільки трохи видозмінюватися в інших античних байкарів, зазвучить латиною, на нових мовах Європи - так промине тисяча з гаком років, допоки не з'явиться Жан де Лафонтен (1621-1695). Він теж залишить без змін базову структуру античної байки, але рішуче обновить усю ï форму: перевів текст з прози на вірші, дав байці гнучкий ритм, який і закріпився за жанром на останні триста років, «офранцузив» персонажів байки, надав їм вигляд і стиль культурних буржуа або, хоча б, «міщан у дворянстві». Байка його називається «Во́рон i Лис», але краще буде навести її в оригіналі.

\section{LE CORBEAU ET LE RENARD}

Maître Corbeau, sur un arbre perché,

\footnotetext{
25 На полях дописано: «Тут потрібне ще покликання на одну із „джатак” (мовою палі) з Дав. Індії, де Будда втілювався у Ворону». (Прим. пер.).

26 Давньогрецький оригінал цит за.: [22, с. 43-44]. Цитати з байки в російському перекладі, які наводить В. С. Вахрушев, див.: [6].
} 
Tanait an son bec un fromage.

Maître Renard, par l'odeur alléché,

Lui tint à peu pres ce langage:

«Et bonjour, Monsieur du Corbeau.

Que vous êtes joli! que vous me semblez beau!

Sans mentir, si votre ramage

Se rapporte à votre plumage,

Vous êtes le Phénix des hôtes da ces bois».

A ces mots, le Corbeau ne se sent pas de joie;

Et pour montrer sa belle voix,

Il ouvre un large bec, laisse tomber sa proie.

Le Renard s'en saisit, et dit: «Mon bon Monsieur,

Apprenez que tout flatteur

Vit aux dépens de celui qui l'ecoute.

Cette leçon vaut bien un fromage sans doute».

Le Corbeau honteux et confus

Jura, mais un peu tard, qu'on ne l'y prendrait plus.

Сам автор, повністю відкидаючи панівні в його час правила класицизму, говорить у передмові до першого видання своїх віршованих казок (1665): «Автор бажав перевірити, як краще римуються казки: він переконався, що для цього підходить іррегулярний вірш, бо в ньому немало від прози і ця манера може здатися природною i, значить, найкращою». А між малими казками Лафонтена і його байками різниці майже нема. У 18-ти рядках байки поет створює вигадливу гру різностопних ритмів, детальний аналіз яких не інтендується нами. Легко і невимушено чергуються рядки 3 восьми, семи i десяти, одинадцяти, дванадцяти складів. Відповідно, темп оповіді то пришвидшується, то сповільнюється, що створює гнучкий малюнок статикидинаміки короткого байкового діалога. Просте, але по-своєму віртуозне римування байки: вступний швидкий «катрен» 3 перехресним римуванням, наступний катрен з двох парних рим А-А, Б-Б, далі, точно всередині байки, катрен - монорим (буа́-жуа́-вуá-пруа́), і на закінчення - «секстина» 3 трьох парних рим. Взаємодія зміни форм римування, зміни віршованих розмірів, алітерацій і асонансів породжує численні фоносемантичні афекти, про які, передбачаю, у Л. Щерби мало було і року для аналізу. Чудово перетворилися у Лафонтена і персонажі байки. Перед нами вже не античні Ворон і Лис із їхнім лаконізмом, що переходить у афористичність, 3 їхнім «Ти» в діалозі, а два «метра», тобто поважних буржуа («метром» йменувався і сам Лафонтен, «доглядач вод і лісів» у рідних своїх краях). Уїдливо-підлеслива на початку та глузливо-повчальна в кінці байки мова «метра Лиса» витримана за всіма правилами ввічливості, французької галантності XVII століття - винятково на «Ви» і зі зверненням «пане Вороне». Цій стильовій рисі відповідає і одна важлива деталь в мові Лиса. В «езопівських» варіантах згадувався просто «голос» Ворона («якщо $є$ у тебе голос...». Мабуть, йшлося про голос «справжній»). Лафонтенівський «метр Лис» каже не просто про «голос» пана Ворона, а про його «щебетання», чи, точніше, «спів серед гілок» (французьке «рама́ж»- метонімічне утворення від «рам»-гілка). «Рамаж», та ще й в римі 3 «плюмаж» (прикраса з пір'я) стосовно Ворона - вбивча іронія.

Обробка Лафонтена дала новий імпульс життю давнього сюжету. Багатим 
на варіації виявилося XVIII століття, коли на зміну класицизму йшло Просвітництво. Найбільш оригінальним тут був варіант Г. Е. Лессінга. У вступі до своїх «Байок у прозі» (1759) і в спеціальному «Дослідженні про байку» (той же рік) великий німецький просвітник намагається подолати чарівність байок Лафонтена $з$ їхнім «вишуканим поетичним убранством», 3 їхньою «принадою гармонії», які, на думку Лессінга, затемняють морально-дидактичне підгрунтя і функцію жанру. Відповідно, байка знову, як і в античні часи, повинна стати прозовою, якомога більше простою за стилем і структурою.

Але, звичайно ж, простого повернення до первісного архетипу байки у Лессінга не сталося, бо він як реаліст-просвітник не міг обійтися без психологічних мотивувань, властивих для століття Розуму. В його байці «Ворон і Лисиця» («Der Rabe und die Fuchse») Ворон підбирає шматок отруєного м’яса. Лисиця називає його «могутнім орлом», «посланцем Зевса»! Реакція птаха свідчить про деякий його розум. Ворон здивований і зраділий, що його приймають за орла. «Вже не буду, - подумав він, - розкривати очі лисиці». I він віддає здобич підлеснику, який відразу отруюється і помирає в муках. Мораль: «Нехай би і вам ніколи не добути своїм підлабузництвом нічого, крім отрути, прокляті підлабузники!» Та і в цьому оригінальному варіанті первісна основа байки збережена - перехід здобичі від ворони до лисиці за допомогою улесливої мови останньої.

Російські поети не були настільки оригінальними в обробках лафонтенівської версії, тому що перед ними були інші завдання - вони ще вчилися створювати поезію сучасного гатунку... В середині XVIII століття одна за одною з'являються майже однойменні байки В. Тредіаковського, О. П. Сумарокова та М. Хераскова. Всі троє так чи інакше йдуть за французьким поетом. Не зовсім вдало це вийшло у першого нашого піїти Тредіаковський дав звичний для нього набір зашпортливих фраз, незграбних виразів: «унесть сыра часть случилось», «Ворон, похвалой надмен, мня себе пристойну», «тем самым из его носа растворе́нна / Выпал на землю тот сыр» тощо. Це зразки винайденого поетом «хореїчного гекзаметра», тобто тринадцятискладового розміру 3 сімома наголосами. О. П. Сумароков почав створювати свої байки лише на п'ять-сім років пізніше свого колеги, та різниця виявилася ніби на цілу добу! Власне, Крилову залишилося тільки взяти Сумарокова за взірець i відшліфувати його. Ось як звучить початок сумароковської «Ворони і Лисиці»:

И птицы держатся людского ремесла:

Ворона сыру кус когда-то унесла

И на дуб села,

Села,

Да только лишь ещё ни крошечки не ела.

Усе це аж ніяк не гірше ні від лафонтенівських рядків, ні від пізніших криловських. Та й рядок «Какие ноженьки, какой носок» Крилов, трішки змінивши, переніс у свій текст. Вправи М. Хераскова, що з'явилися водночас 3 сумароковськими, були дещо слабші. Ось початок його «Ворони і Лисиці»: 


\author{
Ворона негде сыр украла \\ И с ним везде летала; \\ Искала места, где б пристойнее ей сесть, \\ Чтобы добычу съесть. \\ Но на дерьво́ лишь села \\ И есть хотела..
}

Стиль Хераскова - це сумароковська легкість і гнучкість, але обтяжені перечіпливими «тредіаковізмами».

Шедевр І. А. Крилова був надрукований 1808 року. Це був період боротьби архаїстів і новаторів (за термінологією Ю. Тинянова), коли Державін завершував свій шлях велично-елегійним і гордим «Лебедем», коли молодий M. І. Гнедич, майбутній колега Крилова по службі в Імператорській бібліотеці, починав свій переклад «Іліади» (Крилов згодом буде одним із добровільних помічників Гнедича у цій справі), коли К. М. Батюшков створив свої романтичні елегії («Элизий», «Выздоровление»), а Жуковський - елегію «Вечер» і знамениті балади. У цій розкоші поезії високого гатунку байки Крилова були, так би мовити, найближчим до прози варіантом віршування. Це i закономірно - вийшовши 3 прози, жанр байки, зберігаючи свою «жанрову пам'ять», завжди до прози тяжіє, хоча і досягає вершин віршової віртуозності. У цьому - одна 3 «ігрових» особливостей байки. Жанр може залишитися самим собою, тільки зберігаючи у собі напутливість, моралізм. Але це заборонено мистецтву. Звідси внутрішнє протиріччя в жанрі - логіка образів байки може спростовувати іiі мораль, хоча і не заперечує iї відкрито.

Так було у Лафонтена. Ще сильніша ця внутрішня суперечливість у Крилова. Як показав Л. С. Виготський, наші симпатії до спритної, розумної Лисиці й антипатія до дурної Ворони перекривають мораль байки, в якій засуджено підлесливість, іії «мерзенність» і «шкідливість». Інакше кажучи, починає діяти логіка мистецтва, яке хотів було (та й то більше в теорії) придушити чи хоча б редукувати в байці Лессінг. Підлесливість «мерзенна». Та якщо вона піднімається до вершин мистецтва (хай навіть не до найвищих), вона вже виправдана. «Тьмы низких истин нам дороже...» Крилов перевищив усіх своїх попередників в «динаміці» образу Лисиці. У Лафонтена, Лессінга, Сумарокова (не кажучи вже про давній варіант) Лисиця відразу береться до промови. У Крилова ï монологу передує «ремарка»: «сырный дух Лису остановил», вона «на цыпочках подходит», «говорит так сладко» тощо. А це надає мові персонажа додаткову переконливість i емоційність. Виникає враження, ніби Лисиця сама вірить у свою брехню - адже так хочеться їсти! Тут у поета, безумовно, вихід на психологізм навіть більш тонкий, ніж у Лессінга. I як майстерно створює Лисиця облудний портрет Ворони! За всіма правилами риторики. Спочатку - загальний план («как хороша!»). Далі деталізація - перелік («шейка», «глазки», пёрушки» тощо). Це перша половина промови - перші їі чотири рядки. Друга половина, теж чотири рядки, енергійне наростання панегірика, але вже базоване на припущенні - «верно, ангельский быть должен голосок!» (йдуть одні суцільні вигуки). Йде полум'яний заклик: «спой, светик, не стыдись!» Позаяк портретна гармонія першої половини промови «вимагає» умовляння ії співом - тільки «спів» може, за словами 
Лисиці, зробити Ворону «царь-птицей». Пародійність цього «псевдо-портрета» очевидна, та безперечним $є$ й ораторське мистецтво Лисиці. Ї̈̈ перемога забезпечена.

Крилов довів до досконалості закладену у давній байці структуру «подвійну експозицію» образу Ворони. Птах поданий «очима автора» - це ж, власне, i погляд Лисиці - як істота нерозумна, ласа на лестощі. А у «звабливому» монолозі Лисиці цьому «реальному» вигляду протиставлений, $\mathrm{i}$ водночас зіставлений з ним, портрет безмежно ідеалізований, гіперболізованопародійний. Автори сюжету, так би мовити, грають інформаційними блоками тексту. «Правда» про Ворону (про іï недоумство) найповніше розкривається за допомогою «брехні» Лисиці, причому ця брехня-ідеалізація має в собі власне спростування (заряд іронії), та воднораз породжує і два типи «правди»: 1) за допомогою «облудної» мови розкрита істинна сутність Ворони (ось вона, гайдептерівська «справжня Не-істина»); 2) облудна промова Лисиці несе практичну користь (тобто прагматичну «правду») іiі суб’єктові - інтенція Лисиці - сир дістається Лисиці.

Можна ще багато говорити і про інші парадокси та «ігрові» суперечності ХT, точніше, його інваріанта. Так, вже в давньому архетипі байки мовчки допускається невідповідність, алогізм, на якому і тримається вся дотепність ситуації: текст передбачає, що обидва персонажа володіють людським розумом і мовою, інакше як би Ворон міг дослухатися до слів Лисиці? Та «мова» птаха виявляється лише неартикульованим пташиним криком-карканням - звідси i жартівливо-філософський висновок античного Лиса про Ворона: «Голос у тебе $\epsilon$, розуму - нема». Поети усвідомлюють цю суперечність - i у Лафонтена, Лессінга Ворон наділений здатністю і до артикульованого мовлення, і до мислення. Проте залишається вихідний парадокс: Лисиця «вільна» у своєму мовленні, Ворон - як і один із персонажів дзен-буддійських коанів - «скутий» неможливістю «сказати» будь-що без втрати бажаного (хоча в деяких варіантах він тримає здобич в кігтях, та загальна структура байки все ж зберігається). Так виникає ще один «ігровий» план у семантиці ХТ - нез'ясовне, але вирішальне для сюжету змішування двох типів умовності в образах здатних говорити звірів, «людського» $\mathrm{i}$ «тваринного» начал у кожному з них.

Будемо підбивати підсумки. Найкраще ігрову природу байок i їм подібних первісно міфологічних жанрів розкрив В. Теккерей в «Увертюрі»першому розділі роману «Ньюкоми» (1855). Це веселе попурі на теми з Езопа i Лафонтена, де байкові персонажі (зокрема i «наші» Ворон 3 Лисицею) розігрують сценки «за мотивами» старовинних сюжетів і ніби транспонують їх в жанр романний. Потім у дію втягуються і автор-розповідач і розумний критик (варіант «проникливого читача»), які сперечаються про запропонований читачеві твір. Але в одному Теккерей упевнений: «Хіба є нові сюжети? Усі типи всіх героїв проходять у всіх цих байках... історії ці розповідалися за сотні років до Езопа: віслюки у львиних шкурах ревли на івриті, хитрі лиси лестили по-етруськи, а вовки гарчали, звичайно ж, на санскриті». Письменник упевнений - тисячолітні типи художніх образів, що мають міфологічну основу, живуть і будуть жити в мистецтві, бо вони, як усі великі символи, мають нескінченну семантичну й естетичну місткість, вони здатні до численних 
жанрових, смислових, структурних трансформацій.

Що дає нам, наприклад, та ж байка (чи казка, бо вона відома і в формі фольклорної казки) про Ворона і Лисицю?

Не тільки шаблонізований сюжет, придатний сьогодні хіба що для пародій. Нi, у цій найкоротшій оповіді, як у точці (= художньому атомі тексту), що вирує смислами, відображена i «змодельована» одна 3 найважливіших граней Буття. Адже Ворона і Лисиця - це люди в масках тварин. Ворона - не просто дурень, а й людина наївна, яка легко вірить «гарному» слову, тим паче що це слово піднімає іï буквально до небес. Ворона проголошується «царем усіх птахів», «цар-птицею», «феніксом лісів», «орлом - птахом Зевса» тощо. Вороні здається, що досягнути цього блаженного становища легко - треба тільки «показати» голос! I один лише їі крик різко змінить становище: Ворона присоромлена, принижена, лестивець тріумфує. Та подібна ситуація безперервно повторюється у житті, в історії: усі нові і нові покоління людей вступають у життя, що підлещує їм, захоплює їх - звідси і «зачаровані мандрівники», «зачаровані душі» світової літератури, людина починає вдавати з себе «царя землі», володаря космосу. Та майя буття підступна: приходить час «втрачених ілюзій» - людина принижена, посоромлена, іiі солодкі омани стосовно самої себе і щодо життя розвіюються. Вона втрачає свої ідеали, а часто і свій «шматок сиру», та й своє життя. У кращому разі залишиться їй цей «сир», за який тепер вона буде міцно триматися, як байковий Ворон, навчений досвідом. Але неперебутня драма буття - люди вічно переживають і будуть переживати гру Сущого і Не-сущого, Істини та Не-істини, Буття і Не-буття, в якій нерозривно переплетені комедія і трагедія, низьке і високе. Шопенгауер казав: доля обійшлася так, що «наше життя повинно містити всі жахи трагедії, та ми при цьому позбавлені навіть можливості зберігати гідність трагічних персонажів, а приречені відбувати всі деталі життя в неминучій ницості характерів комедії» [34, с. 333]. Може, не завжди так. Однак у розглянутих нами байках світова трагедія або драма людства дійсно постає перед нами в казково-комічних формах.

\section{ЛІТЕРАТУРА}

1. Андреева С. В. Иррациональные конструкции в творческом мышлении. Принципьl изучения художественного текста: тезисы 2-х Саратовских стилистических чтений: в 2 ч. Саратов, 1992. Ч. 2. С. 70-71.

2. Богин Б. И. Интенциональность и стиль. Принцииы изучения художественного текста: тезисы 2-х Саратовских стилистических чтений: в 2 ч. Саратов, 1992. Ч. 1. С. 6-8.

3. Борухов Б. Л. Проблема точности и миф о математике. АPT Альманах исследований по искусству: сб. науч. трудов / ред. Б. Л. Борухов. Саратов: Сар. гос. пед. ин-т им. К. А. Федина,, 1993. Вып. 1. С. 177-194.

4. Кайюа Р. Что такое игра? Курьер ЮНЕСКО. 1980. № 2. С. 6-7.

5. Христансен Б. Философия искусства / пер. Г. П. Федотова под ред. Е. В. Аничкова. СПб.: Шиповник, 1911. $291 \mathrm{c.}$

6. Дератани Н. Ф., Тимофеева Н. А. Хрестоматия по античной литературе. Для высш учеб. заведений. Изд. 5-е. Москва: Учпедгиз, тип. «Кр. пролетарий», 1947. Т. I. 632 с.

7. Долинин К. А. Знаковость в степени $\mathrm{N}$ как отличительное свойство художественного текста. Принщипь изучения художественного текста: тезисы 2-х Саратовских 
стилистических чтений: в 2 ч. Саратов, 1992. Ч. 1. С. 22-23.

8. Дымарский М. Я. Норма текстовости и стилевое варьирование. Принципь изучения художественного текста: тезисы 2-х Саратовских стилистических чтений: в 2 ч. Саратов, 1992. Ч. 1. С. 24-25.

9. Эйген М., Винклер Р. Игра жизни. Москва: Наука, 1979. 93 с.

10. Флоренский П. О литературе. Вопросы литературы. 1988. № 1. С. 146-176.

11. Гадамер Г.-Г. Актуальность прекрасного / пер. с нем. Москва: Искусство, 1991. 367 с. (Серия «История эстетики в памятниках и документах»).

12. Гаспаров Б. М. Борис Пастернак: По ту сторону поэтики. (Философия. Музыка. Быт). Москва : Новое литературное обозрение, 2013. 272 c. URL: https://lit.wikireading.ru/48243.

13. Гаспаров Б. М.. Тартуская школа 1960-х годов как семиотический феномен. Ю. М. Лотман и тартуско-московская семиотическая школа. Москва: «Гнозис», 1994. C. 279-294.

14. Гаспаров М. Л. Взгляд из угла. Ю. М. Лотман и тартуско-московская семиотическая школа. Москва: «Гнозис», 1994. С. 299-303.

15. Гиршман М. М. Анализ поэтических произведений А. С. Пушкина, М. Ю. Лермонтова, Ф. И. Тютчева: учеб. пособие для студ. Москва: Высш. школа, 1981. 112 с.

16. Гиршман М. М. Литературное произведение: Теория художественной целостности. 2-е изд., доп. Москва: Языки славянских культур, 2007. 556 с.

17. Горелов И. Н. Верифицируется ли поэтический текст? Принциипь изучения художественного текста: тезисы 2-х Саратовских стилистических чтений: в 2 ч. Саратов, 1992. Ч. 1. С. 19-21.

18. Harris J. F. Language, language games and ostensive definition. Syntess. Dordrecht, 1986. Vol. 69. N. 1. P. 41-49.

19. Хайдеггер М. Разговор на проселочной дороге. Москва: Высш. школа, 1991. 192 с.

20. Гермненевтика. Глоссарий. URL: http://germenevtic.blogspot.com/p/blog-page.html.

21. Киклевич А. К. Семантика художественного текста и возможные миры. Принципы изучения художественного текста: тезисы 2-х Саратовских стилистических чтений: в 2 ч. Саратов, 1992. Ч. 1. С. 29-31.

22. Козаржевский А. Ч. Учебник древнегреческого языка. Москва: Изд-во Моск. ун-та, 1975. $408 \mathrm{c}$.

23. Козлик I. Літературознавчий аналіз художнього тексту / твору в умовах сучасної міжнаукової та міжгалузевої взаємодії. Брно, 2020. 235 с.

24. Левин Ю. И. «За здоровье Её Величества!..» Ю. М. Лотман и тартуско-московская семиотическая школа. Москва: «Гнозис», 1994. С. 309-312.

25. Лозовская Н. В. Принцип моделирования в изучении сказки. Принципь изучения художественного текста: тезисы 2-х Саратовских стилистических чтений: в 2 ч. Саратов, 1992. Ч. 2. С. $124-125$.

26. Лосев А. Ф. История античной эстетики. Последние века: в 2 кн. Москва: Искусство, 1988. Кн. 2. 447 c.

27. Mandelbaum M. Philosophy, History, and the Sciences: Selected Critical Essays. Baltimore: Johns Hopkins University Press, 1984. 336 p.

28. Мейзерский В. М. Прагматические аспекты организации текста. Принципь изучения художественного текста: тезисы 2-х Саратовских стилистических чтений: в 2 ч. Саратов, 1992. Ч. 1. С. 41-42.

29. Мокиенко В. М. Образы русской речи: Историко-этимологические и этнолингвистические очерки фразеологии. Ленинград: Изд-во Ленингр. ун-та, 1986. 280 с. 30. Norris C. Deconstruction: Theory and Practice. London; New York : Methuen, 1982. 157 p.

31. Пастернак Б. Стихотворения и поэмы / вступит. ст. А. Д. Синявского; сост., подгот. текста и примеч. Л. А. Озерова. Москва; Ленинград: Сов. писатель, 1965. 731 с. (Б-ка поэта. Большая серия. Второе изд.).

32. Пономаренко Е. В., Пономаренко С. В., Офман Г. Ю., Хавкин В. П. Почва как она есть. Природа. 1993. № 3. С. 16-26.

33. Репин В. Дверь в единый мир науки и искусства. Наука и жизнь. 1994. № 3. С. 59-60. 
34. Шопенгауеэр А. Мир как воля и представление / пер. Ю. И. Айхенвальда. Москва: И. Н. Кушнерев и К ${ }^{\mathrm{o}}, 1900$. Т. І: кн. 1-4. 552 с.

35. Седов К.Ф. О природе художественного текста. АРT Альманах исследований по искусству: сб. науч. трудов / ред. Б. Л. Борухов. Саратов: Сар. гос. пед. ин-т им. К. А. Федина,, 1993. Вып. 1. С. 5-15.

36. Шиллер Ф. Статьи по эстетике / пер. А. Г. Горнфельда, Э. Л. Радлова ; прим. А. Г. Горнфельда, А. А. Сидорова. Москва; Ленинград: Аcademia, 1935. 672 с.

37. Штайн К. Е. Использование феноменологического метода в процессе анализа поэтических текстов. Принциипы изучения художественного текста: тезисы 2-х Саратовских стилистических чтений: в 2 ч. Саратов, 1992. Ч. 1. С. 62-64.

38. Sprachspiel und Methode: zum Stand der Wittgenstein-Discussion / herausgegeben von Dieter Birnbacher und Armin Burkhardt. Berlin ; New York : de Gruyter, 1985. 211 p.

39. Степанов Н. И. Наука и игра: сопоставление и аналогия. Теория познания и современная физика. Москва: Наука, 1984. С. 75-87.

40. Требик О. Персонажний код кумулятивної казки: Коза. Слов'янський світ. 2018. Вип. 17. C. 143-156. URL: http://nbuv.gov.ua/UJRN/slsv_2018_17_12.

41. Вахрушев В. Принципы изучения художественного текста (тезисы 2-х Саратовских чтений), части 1, 2. Волга. [Саратов] 1993. № VIII. С. 158-159.

42. Вовк В. Н. Языковая метафора в художественной речи. Природа вторичной номинации. Киев: Наук. думка, 1986. 143 с.

43. Выготский Л. С. Психология искусства. Изд. 2-е, доп. Москва: Искусство, 1968. 576 с.

44. Ярошевский М. Г. Психология в XX столетии. Теоретические проблемы развития психологической науки. Москва: Изд-во полит. литературы, 1974. 447 с.

45. Егоров Б. Ф. Полдюжины поправок. Ю. М. Лотман $u$ тартуско-московская семиотическая школа. Москва: «Гнозис», 1994. С. 304-308.

\section{REFERENCES}

1. Andreeva, S.V. (1992), "Irrational constructions in creative thinking", Principles of Studying Literary Text: Abstracts of 2 Saratov Stylistic Readings ["Irratsionalnyie konstruktsii v tvorcheskom myishlenii", Printsipyi izucheniya hudojestvennogo teksta: tezisyi 2-kh Saratovskih stilisticheskih chteniy], Saratov, pp. 70-71. (in Russian).

2. Bogin, B.I. (1992), "Intentionality and style", Principles of Studying Literary Text: Abstracts of 2 Saratov Stylistic Readings ["Intentsionalnost i stil", Printsipyi izucheniya hudojestvennogo teksta: tezisyi 2-kh Saratovskih stilisticheskih chteniy], Saratov, pp. 6-8. (in Russian).

3. Borukhov, B.L. (1993), "The problem of accuracy and the myth of mathematics" ["Problema tochnosti i mif o matematike"], ART Almanakh issledovaniy po iskusstvu: sb. nauch. trudov, Saratov, Issue 1, pp. 177-194. (in Russian).

4. Caillois, R. (1980), "What is a game?" ["Chto takoe igra?"], Kurer YUNESKO, No. 2, pp. 6-7. (in Russian).

5. Christiansen, B. (1911), Philosophy of art, trans. from German [Filosofiya iskusstva, per. s nem.], Shypovnik, SPb., 291 p. (in Russian).

6. Deratani, N.F. and Timofeeva, N.A. (1947), Reader on ancient literature, $5^{\text {th }}$ ed. [Khrestomatiya po antichnoy literature, izd. 5-ye], Uchpedgiz, Moscow, Vol. I, 632 p. (in Russian).

7. Dolinin, K.A. (1992), "Signity in degree N as a distinctive property of a literary text", Principles of Studying Literary Text: Abstracts of $2^{\text {nd }}$ Saratov Stylistic Readings ["Znakovost v stepeni N kak otlichitelnoe svoystvo khudojestvennogo teksta", Printsipy izucheniya khudojestvennogo teksta: tezisy 2-h Saratovskikh stilisticheskikh chteniy], Saratov, pp. 22-23. (in Russian).

8. Dymarsky, M.Ya. (1992), "Norm of textuality and style variation", Principles of Studying Literary Text: Abstracts of 2 Saratov Stylistic Readings ["Norma tekstovosti i stilevoe varirovanie", Printsipy izucheniya khudojestvennogo teksta: tezisy 2-kh Saratovskikh stilisticheskikh chteniy], Саратов, 1992. Ч. 1. С. 24-25. (in Russian).

9. Eigen, M. and Winkler, R. (1979), Game of life [Igra jizni], Nauka, Moscow, 93 p.

10. Florensky, P. (1988), “About literature" [“O literature”], Voprosy literatury, No. 1, pp. 146-176. (in Russian). 
11. Gadamer, H.-G. (1991), Relevance of the beautiful, trans. from German [Aktualnost prekrasnogo, per. s nem.], Iskusstvo, Moscow, 367 p. (in Russian).

12. Gasparov, B.M. (2013), Boris Pasternak: On the other side of poetics. (Philosophy. Music. Life) [Boris Pasternak: Po tu storonu poetiki. (Filosofiya. Muzyka. Byt)], Novoe literaturnoe obozrenie, Moscow, 272 p., available at: https://lit.wikireading.ru/48243. (in Russian).

13. Gasparov, B.M. (1994), "The Tartu School of the 1960s as a Semiotic Phenomenon", Yu.M. Lotman and the Tartu-Moscow semiotic school ["Tartuskaya shkola 1960-h godov kak semioticheskiy fenomen", YU.M. Lotman i tartusko-moskovskaya semioticheskaya shkola], Gnozis, Moscow, pp. 279-294. (in Russian).

14. Gasparov, M.L. (1994), "Looking from the corner", Yu.M. Lotman and the Tartu-Moscow semiotic school ["Vzglyad iz ugla", YU.M. Lotman i tartusko-moskovskaya semioticheskaya shkola], Gnozis, Moscow, pp. 299-303. (in Russian).

15. Girshman, M.M. (1981), Analysis of the poetry of A.S. Pushkin, M.Yu. Lermontov, F.I. Tyutchev [Analiz poeticheskikh proizvedeniy A.S. Pushkina, M.YU. Lermontova, F.I. Tyutcheva], Vyssh. shkola, Moscow, 112 p. (in Russian).

16. Girshman, M.M. (2007), Literary work: Theory of artistic integrity [Literaturnoe proizvedenie: Teoriya khudojestvennoy tselostnosti, 2-e izd., dop], Yazyki slavyanskikh kultur, Moscow, 556 p. (in Russian).

17. Gorelov, I.N. (1992), "Is the poetic text verified?", Principles of Studying Literary Text: Abstracts of 2 Saratov Stylistic Readings ["Verifitsiruetsya li poeticheskiy tekst?", Printsipy izucheniya khudojestvennogo teksta: tezisy 2-kh Saratovskikh stilisticheskikh chteniy], Saratov, C. 19-21. (in Russian).

18. Harris, J.F. (1986), “Language, language games and ostensive definition”, Syntess, Vol. 69 No. 1, p. 41-49. (in English).

19. Heidegger, M. (1991), [Разговор на проселочной дороге], Vyssh. shkola, Moscow, 192 p. (in Russian).

20. Hermeneutics Glossary [Germnenevtika. Glossariy], available at: http://germenevtic.blogspot.com/p/blog-page.html. (in Russian).

21. Kiklevich, A.K. (1992), "Semantics of Literary Text and Possible Worlds", Principles of Studying Literary Text: Abstracts of 2 Saratov Stylistic Readings ["Semantika hudojestvennogo teksta i vozmojnyie miry", Printsipy izucheniya khudojestvennogo teksta: tezisy 2-kh Saratovskikh stilisticheskikh chteniy], Saratov, pp. 29-31. (in Russian).

22. Kozarzhevsky, A. Ch. (1975), Ancient Greek textbook [Uchebnik drevnegrecheskogo yazyka], Izd-vo Mosk. un-ta, Moscow, 408 p. (in Russian).

23. Kozlyk, I. (2020), Literary critic analysis of fictious text/work in the conditions of modern inter-scientific and interdisciplinary interaction [Literaturoznavchyi analiz khudozhnoho tekstu / tvoru v umovakh suchasnoi mizhnaukovoi ta mizhhaluzevoi vzaiemodii], Brno, 235 p. (in Ukrainian).

24. Levin, Yu.I. (1994), "For the health of Her Majesty!..”, Yu.M. Lotman and the Tartu-Moscow semiotic school ["Za zdorovye Eyo Velichestva",YU.M. Lotman i tartusko-moskovskaya semioticheskaya shkola], Gnozis, Moscow, pp. 309-312. (in Russian).

25. Lozovskaya, N.V. (1992), "The principle of modeling in the study of a fairy tale", Principles of Studying Literary Text: Abstracts of 2 Saratov Stylistic Readings ["Printsip modelirovaniya v izuchenii skazki", Printsipy izucheniya khudojestvennogo teksta: tezisy 2-kh Saratovskikh stilisticheskikh chteniy], Saratov, pp. 124-125. (in Russian).

26. Losev, A.F. (1988), History of ancient aesthetics. Recent centuries: in 2 books, Book 2, [Istoriya antichnoy estetiki. Poslednie veka: v 2-kh kn., kn. 1], Искусство, Москва, 447 p. (in Russian).

27. Mandelbaum, M. (1984), Philosophy, History, and the Sciences: Selected Critical Essays, Johns Hopkins University Press, Baltimore, 336 p. (in English).

28. Meyzerskiy, V.M. (1992), "Pragmatic aspects of text organization", Principles of Studying Literary Text: Abstracts of 2 Saratov Stylistic Readings ["Pragmaticheskie aspekty organizatsii teksta", Printsipy izucheniya khudojestvennogo teksta: tezisy 2-kh Saratovskikh stilisticheskikh chteniy], Saratov, pp. 41-42. (in Russian). 
29. Mokiyenko, V.M. (1986), Images of Russian speech: Historical, etymological and ethnolinguistic essays on phraseology [Obrazy russkoy rechi: Istoriko-etimologicheskie $i$ etnolingvisticheskie ocherki frazeologii], Izd-vo Leningr. un-ta, Leningrad, 280 p. (in Russian).

30. Norris, C. (1982), Deconstruction: Theory and Practice, Methuen, London, New York, 157 p. (in English).

31. Pasternak, B. (1965), Poems and poems [Stihotvoreniya i poemy], Sov. pisatel, Moscow, Leningrad, 731 p. (in Russian).

32. Ponomarenko, Ye.V., Ponomarenko, S.V., Ofman, G.Yu. and Khavkin, V.P. (1993), "The soil as it is" ["Pochva kak ona est"], Priroda, No 3, pp. 16-26. (in Russian).

33. Repin, V. (1994), "The door to a single world of science and art" ["Dver v edinyi mir nauki i iskusstva "], Nauka i zhizn, No. 3, pp. 59-60. (in Russian).

34. Schopenhauer, A. (1900), The World as Will and Representation, Vol. I, trans. from German [Mir kak volya i predstavlenie, T. I: kn. 1-4], I.N. Kushntetv i K ${ }^{\circ}$, Moscow, 552 p. (in Russian).

35. Sedov, K.F. (1993), " On the nature of artistic text" ["O prirode khudozhestvennogo teksta"], ART Almanakh issledovaniy po iskusstvu: sb. nauch. trudov, Saratov, Issue 1, pp. 5-15. (in Russian). 36. Schiller, F. (1935), Articles on aesthetics [Stati po estetike], Academia, Moscow, Leningrad, 672 p. (in Russian).

37. Shtain, K.Ye. (1992), "The use of the phenomenological method in the analysis of poetic texts", Principles of Studying Literary Text: Abstracts of 2 Saratov Stylistic Readings ["Ispolzovanie fenomenologicheskogo metoda V protsesse analiza poetichesk", Printsipy izucheniya khudojestvennogo teksta: tezisy 2-kh Saratovskikh stilisticheskikh chteniy], Saratov, pp. 62-64. (in Russian).

38. (1985), Sprachspiel und Methode: zum Stand der Wittgenstein-Discussion / herausgegeben von Dieter Birnbacher und Armin Burkhardt, de Gruyter, Berlin, New York, 211 p. (in German).

39. Stepanov, N.I. (1984), "Science and play: juxtaposition and analogy", Theory of knowledge and modern physics ["Nauka i igra: sopostavlenie i analogiya", Teoriya poznaniya i sovremennaya fizika], Nauka, Moscow, pp. 75-87. (in Russian).

40. Trebyk, O. (2018), "Character code of a cumulative fairy tale: Goat" ["Personazhnyi kod kumuliatyvnoi kazky: Koza"], Slovianskyi svit, Issue 17, pp. 143-156, available at: http://nbuv.gov.ua/UJRN/slsv_2018_17_12. (in Ukrainian).

41. Vakhrushev, V. (1993), "Principles of Studying Literary Text (abstracts of 2 Saratov Stylistic Readings), parts 1, 2" ["Printsipy izucheniya khudojestvennogo teksta: tezisy 2-kh Saratovskikh stilisticheskikh chteniy”'], Volga, No. VIII. pp. 158-159. (in Russian).

42. Vovk, V.N. (1986), Linguistic metaphor in artistic speech. The nature of the secondary nomination [Yazyikovaya metafora $v$ khudojestvennoy rechi. Priroda vtorichnoy nominatsii], Nauk. dumka, Kiev, 143 p. (in Russian).

43. Vygotsky, L.S. (1968), Psychology of Art, $2^{\text {nd }}$ ed., add. [Psihologiya iskusstva, izd. 2-e, dop.], Iskusstvo, Moscow, 576 p. (in Russian).

44. Yaroshevsky, M.G. (1974), Psychology in the XX century. Theoretical problems of the development of psychological science [Psihologiya $v$ XX stoletii. Teoreticheskie problemy razvitiya psihologicheskoy nauki], Izd-vo polit. literatury, Moscow, 447 p. (in Russian).

45. Yegorov, B.F. (1994), "Half a dozen amendments", Yu.M. Lotman and the Tartu-Moscow semiotic school ["Poldyujinyi popravok", Yu.M. Lotman i tartusko-moskovskaya semioticheskaya shkola], Gnozis, Moscow, pp. 304-308. (in Russian).

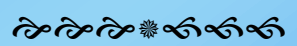

